\title{
EVALUASI PEMAHAMAN MASYARAKAT TENTANG PEMOTONGAN HALAL RPU DI KOTA MAKASSAR
}

\section{Evaluation of Community's Understanding about Halal Slaughterhouse for Poultry in Makassar City}

\author{
Idris*, Aminuddin Saade, dan Siti Sartika Putri Kinanti Surya \\ Politeknik Pembangunan Pertanian Gowa \\ Jl Malino km 7. Romanglompoa, Kecamatan Bontomarannu, Kabupatan Gowa Provinsi Sulawesi Selatan \\ *e-mail: idris@pertanian.co.id
}

Received: 18 September 2021; Accepted: 21 Oktober 2021; Published: 25 Desember 2021

\begin{abstract}
ABSTRAK
Kajian ini bertujuan untuk mengetahui pemahaman masyarakat tentang pemotongan halal RPU di Kota Makassar. Kajian ini dilaksanakan pada bulan Mei-Juni 2021, bertempat di Kecamatan Ujung Tanah Kota Makassar. Metode penelitian yang akan digunakan adalah penelitian kuantitatif deskriptif, yaitu penelitian menjelaskan atau menggambarkan suatu fenomena,dalam hal ini Pemahaman masyarakat tentang pemotongan halal di RPU yang berada di Kec Ujung Tanah Kota Makassar. Variabel yang di amati adalah pemahaman masyarakat dengan sub variabel RPU dan pemotongan halal, adapun indikator dari RPU yaitu keberadaan RPU dan RPU bersertifikat halal, selanjutnya indikator pemotongan halal yaitu ayam dari pemotongan halal dan cara pemotongan halal. Hasil kajian ini menunjukkan pemahaman masyarakat terhadap pemotongan halal di Kota Makassar berada di kategori cukup mengetahui, penelitian tersebut meliputi variabel RPU dan pemotongan halal. Efektivitas penyuluhan mencapai presentase 55,42\% termasuk dalam kategore cukup efektif.
\end{abstract}

\section{Kata Kunci: Evaluasi, pemotongan halal, penyuluhan}

\section{PENDAHULUAN}

Prioritas pembangunan peternakan Indonesia di masa yang akan datang cenderung berada di luar pulau Jawa khususnya Sulawesi. Salah satu pertimbangan utamanya adalah masih tersedianya lahan yang luas dan kepadatan penduduk yang masih sedikit, memberikan prospek pada pembangunan usaha peternakan khususnya unggas.Daging ayam merupakan bahan pangan asal ternak yang digemari oleh masyarakat karena gizinya tinggi, harganya tergolong murah, dan penting untuk memenuhi kebutuhan protein hewani.

Salah satu tahap yang sangat menentukan kualitas dan keamanan daging dalam mata rantai penyediaan daging adalah tahap di rumah pemotongan hewan (RPU). Di RPU ini hewan disembelih dan terjadi perubahan (konversi) dari otot (hewan hidup) ke daging, serta dapat terjadi pencemaran mikroorganisme terhadap daging, terutama pada tahap eviserasi (pengeluaran jeroan). Penanganan hewan dan daging di RPU yang kurang baik dan tidak higienis akan berdampak terhadap kehalalan, mutu dan keamanan daging yang dihasilkan. Oleh sebab itu, penerapan sistem jaminan mutu dan keamanan pangan di RPU sangatlah penting, atau dapat dikatakan pula sebagai penerapan sistem produk safety pada RPU. Aspek yang perlu diperhatikan dalam sistem tersebut adalah higiene, sanitasi, kehalalan, dan kesejahteraan hewan.

Seiring dengan hal itu, masih banyak ditemukan pelaku usaha yang tidak memperhatikan aspek Aman, Sehat, Utuh, dan Halal (ASUH), bahkan cenderung mengabaikan hak konsumen dalam hal ini masyarakat (Direktorat Kesmavet dan Pasca Panen, 2010). Menurut Sahardi (2004), kata

Diterbitkan Oleh, 
ASUH memiliki pengertian sebagai berikut : Aman berarti tidak mengandung mikroorganisme dan residu yang dapat menyebabkan penyakit, Sehat berarti Memiliki zat-zat yang berguna bagi kesehatan dan pertumbuhan tubuh, Utuh berarti Tidak dicampur dengan bagian lain dari hewan tersebut atau bagian dari hewan lainnya, dan Halal berarti dipotong dan ditangani sesuai dengan syariat agama Islam.

Daging yang berasal dari Rumah Potong Unggas (RPU) yang telah disetujui Pemerintah Indonesia antara lain setelah dipenuhinya persyaratan keamanan maupun kehalalannya. Seiring dengan hal tersebut, maka kebutuhan akan pangan asal hewan yang berkualitas, bergizi dan aman dikonsumsi, akan menjadi tuntutan masyarakat. Oleh karena itu, maka dilakukan evaluasi pemahaman pada masyarakat terhadap pemotongan halal di RPU.

\section{METODE PENELITIAN}

\section{Tempat dan Waktu}

Penelitian ini dilaksanakan di Kecamatan Ujung Tanah Kota Makassar pada bulan Mei-Juni 2021 dan penyuluhan di laksanakan di Tamangapa, Kecamatan Manggala, Kota Makassar.

\section{Alat dan Bahan}

Alat dan bahan yang digunakan dalam penelitian ini yaitu alat tulis, kuesioner dan kamera. Sedangkan alat yang digunakan untuk penyuluhan yaitu laptop, LCD, leaflet, dan kamera.

\section{Metode Pelaksanaan}

Metode penelitian yang akan digunakan adalah penelitian kuantitatif deskriptif, yaitu penelitian menjelaskan atau menggambarkan suatu fenomena,dalam hal ini Pemahaman masyarakat tentang pemotongan halal di RPU yang berada di Kec Ujung Tanah Kota Makassar.

\section{Populasi dan Sampel}

Populasi dalam penelitian ini adalah konsumen yang melakukan pembelian di sekitar RPU. Berhubung jumlah populasi cukup besar dimana peneliti memiliki keterbatasan waktu, tenaga, dan biaya.
Maka dilakukan pengambilan sampel. Adapun metode yang dalam pengambilan sampel adalah teknik Probability Sampling dengan cara Sampel acak yaitu 44 sampel.

\section{Teknik Pengumpulan Data}

1. Data Primer

Data primer adalah data yang diperoleh dari hasil observasi dan pengamatan langsung pada objek penelitian.

2. Data Sekunder

Data sekunder adalah data yang diperoleh melalui dokumen-dokumen pada kantor desa dan kantor BPP serta instansi terkait lainnya untuk melengkapi data yang dibutuhkan.

\section{Analisis data}

Analisa data yang digunakan pada penelitian ini statistik deskriptif dengan menggunakan pengelompokan, penyederhanaan, serta penyajian data seperti tabel distribusi frekuensi dan pengukuran dengan menggunakan skala likert.

Menurut Riduwan (2008) bahwa skala likert digunakan untuk mengukur sikap, pendapat dan pemahaman seseorang atau sekelompok tentang kejadian atau gejala sosial. Dengan menggunakan skala likert, maka variabel yang akan diukur dijabarkan menjadi indikator-indikator yang dapat diukur. Kemudian indikator tersebut dijadikan sebagai titik tolak untuk menyusun itemitem instrumen yang dapat berupa pernyataan atau pertanyaan. Setiap jawaban dihubungkan dengan bentuk pernyataan atau dukungan pemahaman yang diungkapkan dengan kata kata yang dikategorikan sebagai berikut:

$\begin{array}{ll}\text { Sangat mengetahui } & : 4 \\ \text { Mengetahui } & : 3 \\ \text { Cukup mengetahui } & : 2 \\ \text { Tidak mengetahui } & : 1\end{array}$

\section{Parameter Pengamatan}

Parameter yang di amati yaitu pemahaman masyarakat tentang pemotongan halal di Rumah Pemotongan Unggas pada konsumen yang melakukan pembelian ditempat tersebut. 
Tabel 1. Parameter pengamatan

\begin{tabular}{cll}
\hline Variabel & \multicolumn{1}{c}{ Sub Variabel } & \multicolumn{1}{c}{ Indkator } \\
\hline Pemahaman masyarakat & a. RPU & $\begin{array}{l}\text { 1. Keberadaan RPU } \\
\end{array}$ \\
& b. Pemotongan Halal & 2. RPU bersertifikat halal \\
& & 1. Ayam dari pemotongan halal \\
& & 2. Cara pemotongan halal
\end{tabular}

\section{RPU (Rumah Potong Unggas)}

Untuk mengukur pemahaman masyarakat tentang RPU dengan menggunakan asumsi dasar menggunakan interval kelas dan rentang kelas dengan kategori sebagai berikut :
Sangat Mengetahui
: 286-352
Mengetahui
: 220-285
Cukup Mengetahui
: 154-219
Tidak Mengetahui
: 88-153

\section{Pemotongan Halal}

Untuk mengukur pemahaman masyarakat tentang pemotongan halal dengan menggunakan asumsi dasar menggunakan interval kelas dan rentang kelas dengan kategori sebagai berikut :
Sangat Mengetahui
: 286-352
Mengetahui
: 220-285
Cukup Mengetahui
: 154-219
Tidak Mengetahui
: 88-153

\section{Nilai Pemahaman Secara Keseluruhan}

Untuk mengetahui keseluruhan nilai dari pemahaman masyarakat Terhadap pemotongan halal di RPU, maka digunakan klasifikasi/pengelompokan dengan kategori sebagai berikut :

Sangat Mengetahui $\quad: 572-704$

Mengetahui : :440-571

Cukup Mengetahui : :308-439

Tidak Mengetahui : $176-307$

Sangat Tidak Terganggu $\quad$ : 176-316,8

\section{Desain Penyuluhan}

Desain penyuluhan merupakan alat bantu bagi penyuluh sebelum melakukan penyuluhan dengan melihat pertimbangan berbagai aspek analisis kebutuhan, masalah, tujuan yang ingin dicapai, metode serta teknik penyuluhan yang akan digunakan agar proses penelitian tentang pemahaman tentang pemotongan halal.

\section{Identifikasi Masyarakat Responden RPU}

Identifikasi potensi sasaran dilakukan untuk mengetahui karakteristik masyarakat yang mencakup jumlah masyarakat berdasarkan kelompok umur, tingkat pendidikan, pengalaman beternak, jumlah kepemilikan ternak dan tanggungan keluarga.

\section{Penetapan Materi, Metode, Media dan Teknik Penyuluhan}

Materi penyuluhan yang dibawakan dalam kegiatan penyuluhan adalah materi yang berkaitan dengan penelitian tentang pemotongan halal. Metode penyuluhan yang digunakan adalah metode pendekatan perorangan terhadap sasaran, tentang pemotongan halal. Media yang digunakan dalam pelaksanaan penyuluhan berupa folder dan peta singkap. Teknik penyuluhan yang digunakan adalah ceramah dan diskusi dengan anggota Kelompok Tani yang menjadi peserta penyuluhan.

\section{Pelaksanaan Penyuluhan}

Kegiatan penyuluhan diawali dengan persiapan materi yang dilengkapi dengan lembar persiapan menyuluh (LPM), sinopsis dan kuesioner sebagai alat ukur untuk mengetahui sejauh mana tingkat keberhasilan penyuluhan tentang materi yang disampaikan.

\section{Evaluasi Desain Penyuluhan}

Metode evaluasi yang digunakan untuk mengetahui tingkat pengetahuan dan sikap responden dengan menggunakan Rating Scale atau skala nilai kemudian ditabulasi dan diolah dengan menggunakan garis Continuum. Evaluasi dilakukan untuk mengetahui pemahaman masyarakat terhadap materi yang disampaikan.Evaluasi awal (pre test) untuk mengukur tingkat pengetahuan, sikap dan keterampilan awal responden terhadap

Diterbitkan Oleh, 
materi penyuluhan yang disampsikan. Evaluasi akhir (post test) untuk mengukur pengetahuan dan sikap dilakukan pada akhir dengan metode kelompok.Jumlah keseluruhan pertanyaan yang diajukan sebanyak 10 pertanyaan dari 2 aspek yang diukur (pengetahuan dan sikap).

Evaluasi dilakukan untuk mengukur pengetahuan, sikap dan keterampilan dengan mengajukan pertanyaan (kuesioner) kepada masyarakat, masing-masing 5 pertanyaan pengetahuan, dan 5 pertanyaan sikap. Evaluasi dilakukan sebelum dan sesudah penyuluhan. Hasil penilaian tes awal dan tes akhir diberi skor dengan ketentuan: jawaban a nilai 4 , jawaban b nilai 3, jawaban c nilai 2, dan jawaban d nilai 1 selanjutnya hasil tersebut ditabulasi dan diolah dengan rumus Ginting (1991).

\section{HASIL DAN PEMBAHASAN}

\section{Pemahaman Masyarakat}

Pemahaman masyarakat adalah kemampuan masyarakat dalam mengerti tentang pemotongan halal di RPU yang berada di Kecamatan Ujung Tanah Kota Makassar. Indikator dari variabel penelitian ini adalah:

1. RPU : Keberadaan RPU

2. Pemotongan Halal : Pengetahuan tentang pemotongan halal

3.

Pemahaman masyarakat terhadap pemotongan halal di RPU dapat dijelaskan sebagai berikut :

Tabel 2. Jawaban responden mengenai pemahman masyarakat dengan sub variabel RPU, indikator keberadaan RPU Di Kecamatan Ujung Tanah, Kota Makassar

\begin{tabular}{llcccc}
\hline \multicolumn{1}{c}{ Indikator } & Kategori jawaban & Nilai skor & $\begin{array}{c}\text { Frekuensi } \\
\text { (orang) }\end{array}$ & Jumlah & $\begin{array}{c}\text { Persentase } \\
(\%)\end{array}$ \\
\hline Keberadaan & Sangat Mengetahui & 4 & 2 & 8 & 4,54 \\
RPU & Mengetahui & 3 & 6 & 18 & 13,64 \\
& Cukup Mengetahui & 2 & 13 & 26 & 29,54 \\
& Tidak Mengetahui & 1 & 23 & 23 & 52,28 \\
$\quad$ Total & & 44 & 75 & 100,00 \\
\hline
\end{tabular}

Tabel 3. Jawaban responden mengenai pemahaman masyarakat dengan sub Variabel RPU, indikator keberadaan RPU Di Kecamatan Ujung Tanah, Kota Makassar

\begin{tabular}{|c|c|c|c|c|c|}
\hline Indikator & Kategori jawaban & Nilai skor & $\begin{array}{l}\text { Frekuensi } \\
\text { (orang) }\end{array}$ & Jumlah & $\begin{array}{c}\text { Persentase } \\
(\%)\end{array}$ \\
\hline Membeli & Sangat Mengetahui & 4 & 0 & 0 & 0 \\
\hline \multirow[t]{4}{*}{ Ayam di RPU } & Mengetahui & 3 & 1 & 3 & 2,28 \\
\hline & Cukup Mengetahui & 2 & 5 & 10 & 11,36 \\
\hline & Tidak Mengetahui & 1 & 38 & 38 & 86,36 \\
\hline & Total & & 44 & 51 & 100,00 \\
\hline
\end{tabular}

\section{Rumah Potong Unggas (RPU)}

Rumah potong unggas (RPU) adalah Suatu bangunan dengan desain dan konstruksi khusus yang memenuhi persyaratan teknis dan higiene tertentu, serta di gunakan sebagai tempat memotong unggas bagi konsumsi masyarakat umum dan sudah bersertifikat halal, namun di kecamatan Ujung Tanah Kota Makassar hanya memiliki 1 RPU dan memiliki 3 pasar sehingga masyarakat tidak membeli ayam di RPU saja. Untuk melihat pemahaman masyarakat dapat dilihat pada tabel 2. Berdasarkan tabel 2 dan 3. Menunjukan bahwa total skor untuk sub variabel RPU di peroleh 126 skor dengan kategori tidak mengetahui yang berarti berada di kategori terendah. Diantara indikator diperoleh nilai skor yang sangat tinggi yaitu 38 skor pada indikator 
tidak mengetahui. Tinggi skor tersebut disebabkan karena sebagian besar masyarakat merasa kurang mengetahui adanya RPU.

\section{Pemotongan Halal}

Pemotongan atau penyembelihan ialah menyempurnakan kematian. Dan menurut istilah ialah memutuskan jalan makan, minum, nafas, dan urat nadi pada leher hewan dengan alat tajam selain gigi, kuku, tulang, dan sesuai syari'at. Namun pemotongan halal ini masih belum di anggap serius oleh masyarakat. Untuk melihat pemahaman masyarakat dapat dilihat pada tabel 4 .

Berdasarkan tabel 4 dan 5. Menunjukan bahwa total skor untuk sub variabel Pemotongan Halal di peroleh 213 skor dengan kategori cukup mengetahui yang berarti berada di kategori kedua. Diantara indikator diperoleh nilai skor yang sangat tinggi yaitu 60 skor pada indikator cukup mengetahui. Tinggi skor tersebut disebabkan karena sebagian besar masyarakat cukup mengetahui ayam yang diperoleh harus dari pemotongan halal.

Tabel 4. Jawaban responden mengenai pemahaman masyarakat dengan sub variabel pemotongan halal, indikator ayam dari pemotongan halal Di Kecamatan Ujung Tanah, Kota Makassar

\begin{tabular}{llcccc}
\hline \multicolumn{1}{c}{ Indikator } & \multicolumn{1}{c}{ Kategori jawaban } & Nilai skor & $\begin{array}{c}\text { Frekuensi } \\
\text { (orang) }\end{array}$ & Total & $\begin{array}{c}\text { Persentase } \\
(\%)\end{array}$ \\
\hline Ayam dari & Sangat Mengetahui & 4 & 9 & 36 & 20,46 \\
pemotongan & Mengetahui & 3 & 4 & 12 & 9,09 \\
halal & Cukup Mengetahui & 2 & 30 & 60 & 68,18 \\
& Tidak Mengetahui & 1 & 1 & 1 & 2,27 \\
& $\quad$ Jumlah & & 44 & 109 & 100 \\
\hline
\end{tabular}

Tabel 5. Jawaban responden mengenai pemahaman masyarakat dengan sub variabel rpu, indikator cara pemotongan halal Di Kecamatan Ujung Tanah, Kota Makassar

\begin{tabular}{llcccc}
\hline \multicolumn{1}{c}{ Indikator } & Kategori jawaban & Nilai skor & $\begin{array}{c}\text { Frekuensi } \\
\text { (orang) }\end{array}$ & Total & $\begin{array}{c}\text { Persentase } \\
(\%)\end{array}$ \\
\hline Cara & Sangat Mengetahui & 4 & 11 & 44 & 25 \\
pemotongan & Mengetahui & 3 & 5 & 15 & 11,36 \\
halal & Cukup Mengetahui & 2 & 17 & 34 & 38,64 \\
& Tidak Mengetahui & 1 & 11 & 11 & 25 \\
& $\quad$ Jumlah & & 44 & 104 & 100 \\
\hline
\end{tabular}

Tabel 6. Hasil rekapitulasi penilaian pemahaman masyarakat terhadap pemotongan halal di RPU Di Kecamatan UjungTanah, Kota Makassar

\begin{tabular}{clc}
\hline Variabel & \multicolumn{1}{c}{ Sub variabel } & Nilai \\
\hline Pemahaman masyarakat & 1.RPU & 126 \\
Jumlah & 2.Pemotongan Halal & 213 \\
& & 339 \\
\hline
\end{tabular}

Diterbitkan Oleh, 


\section{Total Pemahaman Secara Keseluruhan}

Penilaian masyarakat di Lingkungan Kecamatan Ujung Tanah, Kota Makassar terhadap pemahaman keseluruhan dapat dilihat pada Tabel 6. Berdasarkan tabel 6 menunjukan bahwa hasil penilaian responden terhadap pemahaman secara keseluruhan dengan total bobot 339 penilaian tersebut meliputi RPU dengan bobot 136, dan Pemotongan Halal dengan bobot 213.

\section{Evaluasi Penyuluhan Peternakan}

Evaluasi penyuluhan dilkukan untuk mengetahui pengetahuan dan sikap responden terhadap materi yang telah disampaikan. Evaluasi yang telah dilakukan adalah evaluasi awal dan evaluasi akhir. Alat yang digunakan untuk mengukur tingkat pengetahuan dan sikap Responden adalah kuesioner dengan jumlah pertanyaan sebanyak 5 untuk pengetahuan dan 5 untuk sikap, sehingga total pertanyaan seluruhnya adalah 10, dengan nilai tertinggi adalah 4 dan nilai terendah 1. Tinggi rendahnya tingkat pengetahuan Responden dapat ditentukan melalui jawaban Responden dari tiap-tiap pertanyaan dalam evaluasi awal dan akhir dengan Responden anggota romangtangaya II sebanyak 25 orang. Hasil evaluasi penyuluhan diharapkan dapat menggambarkan tercapai atau tidaknya program penyuluhan sebagai gambaran hasil kegiatan penyuluhan yang telah dilaksanakan.

Penyuluhan mengenai dampak lingkungan usaha peternakan broiler dapat mengubah tingkat sikap responden sebelum mengikuti penyuluhan dari kategori setuju (S) dengan nilai 255 atau persentase $51 \%$ naik menjadi kategori Sangat Setuju (SS) dengan nilai 412 atau persentase $92,4 \%$ setelah mengikuti kegiatan penyuluhan. Rekapitulasi perolehan skor evaluasi penyuluhan pertanian tentang efektivitas penggunaan kartu tani dapat dilihat pada table 7 .

Tabel 7. Rata-rata tingkat pengetahuan dan sikap responden kelompok tani Romangtangayya II Kelurahan Tamangapa Kecamatan, Manggala, Kota Makassar

\begin{tabular}{|c|c|c|c|c|c|c|c|}
\hline \multirow{2}{*}{ Deskripsi } & \multirow{2}{*}{$\begin{array}{l}\text { Skor } \\
\text { Maks }\end{array}$} & \multicolumn{4}{|c|}{ Nilai yang Diperoleh } & \multicolumn{2}{|c|}{ Perubahan } \\
\hline & & Tes Awal & $\%$ & Tes Akhir & $\%$ & Nilai & $\%$ \\
\hline Pengetahuan & 500 & 247 & $49,4 \%$ & 366 & $73,2 \%$ & 119 & $23,8 \%$ \\
\hline Sikap & 500 & 255 & $51 \%$ & 412 & $82,4 \%$ & 157 & $31,4 \%$ \\
\hline Jumlah & 1000 & 502 & & 778 & & 276 & \\
\hline
\end{tabular}

Berdasarkan table 7. Menunjukkan bahwa penyuluhan dengan materi pemotongan halal di RPU dapat mengubah tingkat pengetahuan dan sikap responden. Sebelum mengikuti penyuluhan, tingkat pengetahuan responden berada pada kategori cukup mengetahui $(49,4 \%)$ dan tingkat sikap responden berada pada kategori setuju $(51 \%)$. Setelah mengikuti penyuluhan, tingkat pengetahuan dan sikap responden meningkat menjadi mengetahui $73,2 \%$ ) dan sangat setuju $(82,4 \%)$.

\section{Efektivitas penyuluhan}

Efektivitas penyuluhan pada kelompok Romangtangayya II Kelurahan Tamangapa yang telah dilaksanakan. Berdasarkan hasil evaluasi awal dan evaluasi akhir maka diperoleh Efektivitas Penyuluhan dengan persentase 55,42\%. Dari hasil perhitungan yang telah dilakukan, maka dapat disimpulkan bahwa penyuluhan yang dilakukan dapat dikategorikan sebagai penyuluhan yang Efektif.

\section{KESIMPULAN}

Berdasarkan hasil analisis dan pembahasan yang telah dilakukan, maka dapat diambil kesimpulan sebagai berikut:

1. Pemahaman Masyarakat terhadap Pemotongan halal di RPU di Kecamatan Ujung Tanah Kota Makassar. Menunjukan bahwa jumlah skor sebanyak 339 untuk pemahaman masyarakat secara keseluruhan skor (308-440), termasuk kategori cukup mengetahui. penilaian tersebut meliputi variabel RPU bahwa total skor 126, untuk pemahaman masyarakat terhadap pemotongan

Diterbitkan Oleh,

Unit Penelitian dan Pengabdian Masyarakat, Politeknik Pembangunan Pertanian Gowa

http://ejournal.polbangtan-gowa.ac.id 
halal di RPU skor $(88$ - 154) dengan kategori Tidak Mengetahui. Hal ini bahwa menurut jawaban responden merasa tidak mengetahui adanya RPU dikarenakan masyarakat lebih sering membeli ayam di pasar yang berada di dekat rumahnya. Selanjutnya dari variabel pemotongan halal dijelaskan bahwa total skor 213, untuk pemahaman masyarakat terhadap pemotongan halal di RPU skor (154 - 220) dengan kategori Cukup Mengetahui. Hal ini bahwa menurut jawaban responden merasa cukup mengetahui ayam potong harus berasal dari pemotongan halal.

2. Hasil evaluasi penyuluhan petani terhadap efektivitas penyuluhan dengan materi pemotongan halal di RPU mengubah tingkat pengetahuan dan sikap responden. Sebelum mengikuti penyuluhan, tingkat pengetahuan responden berada pada kategori cukup mengetahui $(49,4 \%)$ dan tingkat sikap responden berada pada kategori setuju (51\%). Setelah mengikuti penyuluhan, tingkat pengetahuan dan sikap responden meningkat menjadi mengetahui $73,2 \%$ ) dan sangat setuju $(82,4 \%)$. Berdasarkan hasil evaluasi awal dan evaluasi akhir maka diperoleh Efektivitas Penyuluhan dengan persentase 55,42\% (cukup efektif)

\section{DAFTAR PUSTAKA}

Abduh, M,. 2002 .Studi Perbandingan Konsep Pelaksanaan Penyembelihan Binatang Ternak Sapi antara Rumah Sembelihan (Arbotoir) Gong Medang dan Rumah Sembelihan (Tradisional) Dikampung Rawa Besut Terengganu Menurut Hukum Islam. Tesis. Panam Universitas Islam Negeri Suska, hlm.29.

Abubakar. (2003). Mutu Karkas Ayam Hasil Pemotongan Tradisional Dan Penerapan Sistem Hazard Analysis Critical Control Point. Jurnal Litbang Pertanian Vol.22 : 24.

Adjid, D. A. 2001. Membangun Pertanian Modern. Pengembangan Sinar Tani. Jakarta.

Aliss, $\begin{array}{llr}2000 . \quad \text { Penyakit } & \text { Ayam dan } \\ & \text { Penanggulangannya. } \\ \text { Kanisius,Yogyakarta. } & & \text { Penerbit }\end{array}$

Arikunto, S. 2006. Metode Penelitian Kualitatif. Jakarta: Bumi Aksara.

Husein Umar. (2005), Metode Penelitian Untuk Tesis Dan Bisnis, Jakarta: Grafindo Persada.

Mardikanto, T., 2003. Redefisi dan Revitalisasi Penyuluhan Dalam Membentuk Pola Perilaku manusia Pembangunan. IPB Press. Bogor.

Mardikanto, T., 2014. CSR (Corporate Sosial Responsibility) Tanggung Jawab Sosial. Cetakan-1, Bandung, Alfabeta.

Margono. 2004. Metodologi Penelitian Pendidikan, Jakarta : Rineka Cipta.

Nuriyasa, I.M. 2003.Pengaruh Tingkat Kepadatan dan Kecepatan Angin Dalam Kandang Terhadap Indeks Ketidaknyamanan dan Penampilan Ayam Pedaging. Majalah Ilmiah Peternakan, Fakultas Peternakan, Unud. Hal 99-103.

Padmowihardjo, 2002. Metode Penyuluhan Pertanian. Universitas Terbuka, Jakarta.

Saleh ,Al-fauzan 2005., Fiqih Sehari-hari, Gema Insani Press . Jakarta.

Sayyid Sabiq. 1987, Fiqih Sunnah 13, diterjemahkan oleh Kamalaudin A. Marzuki dari Fiqhus Sunnah, PT. Almaeearif. Bandung. Hlm132.

Soeparno. 2004. Ilmu dan Teknologi daging. Gadjah Mada University Press, Yogyakarta. Hal. 5-6: 11-12

Sumardjo. 2010. Penyuluhan Menuju Pengembangan Kapital Manusia dan Kapital Sosial dalam Mewujudkan Kesejahteraan Rakyat. Orasi Ilmiah Guru Besar Tetap Fakultas Ekologi Manusia.

Undang - undang RI No 16 Tahun 2006 Tentang Sistem Penyluhan Pertanian, Perikanan, dan Kelautan. Biro Hukum Departemen Pertanian. Jakarta.

Undang-Undang Nomor 33 Tahun 2014 tentang Jaminan Produk Halal.

Widyantono. 2013, Laporan Praktikum Ilmu Ternak Unggas Sistem Digesti Dan Reproduksi Ayam. Laboratorium Ilmu Ternak Unggas. Bagian Produksi Ternak Fakultas Peternakan. Universitas Gadjah Mada. 
DOI: 10.52625/j-agr-sosekpenyuluhan.v17i2.202

Wirawan, 2012. Evaluasi Teori, Model, Standar, Aplikasi dan Profesi Jakarta:Rajawali Pers

Worthen, B.R \& Sanders, J.R. (1987). Educational Evaluation. Alternative Approaches and Practical Guidelines. New York \& London: Longman Inc

Yuwanta, 2004. Teknik Modren Beternak Ayam. Yasaguna, Jakarta

Zakaria, A, 2002. Standar Teknis Media Penyuluhan Pertanian, Badan
Pengembangan Sumber Daya Manusia Pertanian Departemen Pertanian. Jakarta.

Zakaria, 2006. Modul Dasar-Dasar Penyuluhan Pertanian. Pusat Manajemen Pelatihan Sumberdaya Manusia Pertanan, Ciawi. Bogor

Zuhaili. 2010, Halal dan Haram dalam Islam, Alih bahasa oleh Mu'ammal Hamidy, Surabaya: PT Bina Ilmu Surabaya. Hlm . 60. 